\title{
Evaluation of IFN- $\gamma$ level in peripheral blood mononuclear cell of childhood tuberculosis treated by lactic acid bacteria multi cultures
}

\author{
Faizatul ROSYIDAH ${ }^{1}$ iD, Ni Made MERTANIASIH ${ }^{1}$ (D), ISNAENI ${ }^{2}$ * iD \\ 1 Department of Medical Microbiology, Faculty of Medicine, Universitas Airlangga, Surabaya, Indonesia. \\ 2 Department of Pharmaceutical Chemistry, Faculty of Pharmacy, Universitas Airlangga, Surabaya, Indonesia. \\ * Corresponding Author. E-mail: isna.yudi@gmail.com (I); Tel. +62-081-331 021303.
}

Received: 24 July 2019 / Revised: 03 February 2020/ Accepted: 16 February 2020

\begin{abstract}
At least a half million children in the world are suffering from TB every year and 64.000 children died from TB in 2011. Previous works indicated the ability of probiotic in stimulating the production of IL- 12 and IFN- $\gamma$ which subsequently increased the role of type Th1 responses and improved the balance of Th1-Th2. Antigen combination of Mycobacterium tuberculosis (Mtb) and Lactic Acid Bacteria (LAB) initiated synergistic increase of IFN- $\gamma$ bigger than the level induced by $M t b$ or LAB. This study aimed to analyze the administration effects of LAB multi cultures (Lactobacillus acidophilus, Lactobacillus bulgaricus, Lactobacillus casei, Bifidobacterium bifidum, Bifidobacterium animalis, Lactobacillus plantarum, Streptococcus thermophilus) to the secretion of IFN-ץ on peripheral blood mononuclear cell (PBMC) culture supernatant of childhood tuberculosis patients under medication. The PBMC of the patients isolated from whole blood was culture-treated in 4 groups: (1) without treatment (-MtbCell, -LAB), (2) incubation with $M t b$, without LAB administration ( $+M t b C e l l,-L A B)$, (3) with LAB administration, without incubation with $M t b(-$ $M t b C e l l,+\mathrm{LAB})$, and (4) incubation with $M t b$ and $\mathrm{LAB}$ administration $(+M t b C e l l,+\mathrm{LAB})$, to subsequently be taken the supernatant and to examine IFN- $\gamma$ by using enzyme-linked immunosorbent assay. There was a significant difference in IFN- $\gamma$ assay $(p=0.006)$ between group (1) compared to the group (4). Addition of the LAB multi cultures increased the secretion of IFN- $\gamma$ supernatant on the PBMC culture supernatant of childhood tuberculosis patients under medication. The LAB increased $6.31 \%$ of IFN- $\gamma$ level, while treatment with LAB and $M t b$ increased IFN- $\gamma$ level up to $15.79 \%$ compared to IFN- $\gamma$ level in the PBMC without treatment.
\end{abstract}

KEYWORDS: Mycobacterium tuberculosis; lactic acid bacteria; peripheral blood mononuclear cell; IFN-ץ.

\section{INTRODUCTION}

The incidence of Tuberculosis (TB) in children has been estimated at $6 \%$ of the total TB incidences. The number of positive pulmonary TB patients who are still high in Indonesia with a prevalence of 281/100,000 population and an incidence of 187/100,000 population in 2011 puts children in a vulnerable group [1,2,3].

Infection by Mycobacterium tuberculosis $(M t b)$ unlike other bacterial infections has its own peculiarities, because these bacteria live intracellular. This is one of the factors that complicated treatment [4]. There is an important role for macrophages and $\mathrm{T}$ cells in destroying $M t b$ by which the macrophages activated produce several cytokines including interleukin (IL) 12 which can stimulate the IFN-Y production by Th1 cells and Natural Killer (NK) cells [5,6]. The IFN- $\gamma$ is tasked to strengthen the potential of phagocytes from macrophages infected with the $M t b$ by stimulating the formation of phagolysosomes and free radicals to destroy DNA and cell walls of $M t b$ so that growth is inhibited and subsequently eliminated [4,7].

Bhavanam et al. reported characteristic of immune responses of human peripheral blood mononuclear cell (PBMC) infected by Mtb H37Ra [5]. Level of the IFN- $\gamma$ and other immune parameters were observed at three until eight days after treatment. The levels of INF- $\gamma$, TNF- $\alpha$, IL-4, IL-6, IL-10 and IL-17 in the supernatants of Mtb-infected PBMCs peaked on third day and decreased on the fifth day and eighth day [8].

Recent developments, the use of immune modulator attract attention to overcome $\mathrm{TB}$, mainly due to an increase in the percentage of patients who are resistant to anti-TB drugs. The immune modulator is expected to be used to repair or rebuild immune system that is less than perfect or dysfunction [9]. Today's development of immune modulator in the world of the pharmaceutical industry has taken a lot of attention

How to cite this article: Rosyidah F, Mertaniasih NM, Isnaeni I. Evaluation of IFN-plevel in peripheral blood mononuclear cell of childhood tuberculosis treated by lactic acid bacteria multi cultures. J Res Pharm. 2020; 24(2): 188-195. 
and research from academics, both medicinal plants and probiotics, especially Lactic Acid Bacteria (LAB) groups $[6,10,11]$. The use of probiotic and LAB is increasingly popular, because of its activity both as an antimicrobial and immune modulator. Lactobacillus acidophiluswas reported to be able to increase TNF- $\alpha$ serum of mice [12]. Ghadimi et al. succeeded in proving that the combination of $M t b$ antigen with Lactobacillus rhamnosus GG (LGG) or Bifidobacterium bifidum MF 20/5 (BW) caused a synergistic increase in IFN- $\gamma$ which was statistically greater than the level induced by $M t b$ or each of these probiotics [7]. In previous studies, LAB multi culture (Lactobacillus acidophilus, Lactobacillus bulgaricus, Lactobacillus casei, Bifidobacterium bifidum, Bifidobacterium animalis, Lactobacillus plantarum, Streptococcus thermophilus) was shown to be active in inhibiting the growth of extended-spectrum beta-lactamases (ESBL) and methicilin-resistant Staphylococcus aureus (MRSA) bacteria [13], while Lactobacillus plantarum was also shown to be able to inhibit the growth of Streptococcus mutans [14]. In this study effect of the LAB multicultures on the IFN- $\gamma$ secretion in PBMC culture supernatant of childhoods TB in medication has been evaluated. The treatment to PBMC was performed by LAB multi cultures, without and combined with Mtb-Cells (MtbC).

\section{RESULTS AND DISCUSSION}

\subsection{Qualification of patients}

Patients who were used as subjects in this study had different characters included age, gender; status of medication and other related conditions, although they still met the inclusion criteria (Table 1).

Table 1. Qualification of childhood TB patients.

\begin{tabular}{cll}
\hline No & Patients characters & Qualification \\
\hline 1 & Aged & 2-14 years old \\
2 & Gender & Female 35.3\%; Male 64.7\% \\
3 & Type of TB & Intra pulmonary $52.9 \%$; extra pulmonary $47.1 \%$ \\
4 & Medication status & Intensive 35.7\%; ongoing (II-XII) $64.7 \%$ \\
\hline
\end{tabular}

\subsection{Determination of IFN- $\gamma$ level in serum}

Determination of IFN- $\gamma$ level in subject's serum based on the age, gender, type of TB and medication phase (Table 2) showed no significant differences between the groups.

Table 2. Serum level of IFN- $\gamma$.

\begin{tabular}{|c|c|c|c|c|}
\hline No & Groups & & $\mathbf{N}$ & Mean $(\mathrm{pg} / \mathrm{mL})$ \\
\hline 1 & Aged & $\begin{array}{l}2-7 \text { years old } \\
8-13 \text { years old }\end{array}$ & $\begin{array}{c}7 \\
10\end{array}$ & $\begin{array}{l}0.0870000 \\
0.0811000\end{array}$ \\
\hline 2 & Gender & $\begin{array}{l}\text { Female } \\
\text { Male }\end{array}$ & $\begin{array}{c}6 \\
11\end{array}$ & $\begin{array}{l}0.0883333 \\
0.0809091\end{array}$ \\
\hline 3 & Type of TB & $\begin{array}{l}\text { Intra } \\
\text { pulmonary } \\
\text { extra } \\
\text { pulmonary }\end{array}$ & $\begin{array}{l}9 \\
8\end{array}$ & $\begin{array}{l}0.0838889 \\
0.0831250\end{array}$ \\
\hline 4 & Medication status & $\begin{array}{l}\text { Intensive } \\
\text { ongoing (II-XII) }\end{array}$ & $\begin{array}{c}6 \\
11\end{array}$ & $\begin{array}{l}0.0793333 \\
0.0858182\end{array}$ \\
\hline $\begin{array}{l}5 \\
6\end{array}$ & $\begin{array}{l}\text { Disease severity } \\
\text { Average of serum IFN- } \gamma\end{array}$ & $\begin{array}{l}\text { severe } \\
\text { mild }\end{array}$ & $\begin{array}{c}6 \\
11\end{array}$ & $\begin{array}{c}0.0885000 \\
0.0808182 \\
0.08353+0.0105\end{array}$ \\
\hline
\end{tabular}

\subsection{Determination of IFN- $\gamma$ level in the PBMC samples}

The IFN- $\gamma$ level in the PBMC culture supernatantof 17 patients with childhood TBwho were undergoing treatment achieved $0.076 \mathrm{pg} / \mathrm{mLof} 0.132 \mathrm{pg} / \mathrm{mL}$ with an average of $0.095 \mathrm{pg} / \mathrm{mL}$. Furthermore, in the treatment with $M t b \mathrm{C}, \mathrm{LAB}$ and $(M t b \mathrm{C}+\mathrm{LAB})$, average of the IFN- $\gamma$ level obtained were of $0.078-0.114$ $\mathrm{pg} / \mathrm{mL}, 0.075-0.115 \mathrm{pg} / \mathrm{mL}$, and $0.090-0.179 \mathrm{pg} / \mathrm{mL}$ respectively (Table 3 ). 
It was rational if the highest results were obtained by $M t b C$ and $L A B$ treatment. Fluctuation data might be caused by condition of the patients taken randomly, but are still controlled by inclusion factors. In this study the treatment of $M t b C$ and LAB was only carried out with one concentration, so that in future studies it is necessary to optimize both concentrations. On the other hands, the patient status such as malnutrition and medication phase might be affected the measurement results.

The IFN- $\gamma$ level increased by $6.32 \%$ and $15.79 \%$ compared to control (without treatment) for $(-M t b \mathrm{C}$, $+\mathrm{LAB})$ and $(+M t b \mathrm{C},+\mathrm{LAB})$ respectively. The IFN- $\gamma$ level $0.09694 \mathrm{pg} / \mathrm{mL}$ showed an insignificant increase in treatment with $M t b C$ without LAB compared to the control of $0.09518 \mathrm{pg} / \mathrm{mL}$ (Figure 1). The highest IFN- $\gamma$ supernatant level of $0.11000 \mathrm{pg} / \mathrm{mL}$ was obtained after treatment with $(+M t b \mathrm{C},+\mathrm{LAB})$.

Table 3. Sample characteristic based on the IFN-ץ level in PBMC supernatant.

\begin{tabular}{|c|c|c|c|c|}
\hline \multirow{2}{*}{ Sample } & \multicolumn{4}{|c|}{ IFN- $\gamma$ supernatant level $(\mathrm{pg} / \mathrm{mL})$} \\
\hline & Without treatment & $+\mathrm{MtbC},-\mathrm{LAB}$ & -MtbC, +LAB & $+\mathrm{MtbC},+\mathrm{LAB}$ \\
\hline 1 & 0.076 & 0.078 & 0.075 & 0.091 \\
\hline 2 & 0.092 & 0.101 & 0.095 & 0.116 \\
\hline 3 & 0.080 & 0.083 & 0.076 & 0.090 \\
\hline 4 & 0.097 & 0.096 & 0.096 & 0.110 \\
\hline 5 & 0.132 & 0.112 & 0.109 & 0.115 \\
\hline 6 & 0.098 & 0.114 & 0.107 & 0.108 \\
\hline 7 & 0.106 & 0.112 & 0.113 & 0.115 \\
\hline 8 & 0.104 & 0.109 & 0.109 & 0.107 \\
\hline 9 & 0.110 & 0.101 & 0.111 & 0.125 \\
\hline 10 & 0.107 & 0.104 & 0.115 & 0.179 \\
\hline 11 & 0.084 & 0.095 & 0.088 & 0.096 \\
\hline 12 & 0.098 & 0.101 & 0.088 & 0.100 \\
\hline 13 & 0.089 & 0.089 & 0.110 & 0.102 \\
\hline 14 & 0.094 & 0.097 & 0.111 & 0.105 \\
\hline 15 & 0.087 & 0.093 & 0.105 & 0.096 \\
\hline 16 & 0.087 & 0.075 & 0.107 & 0.097 \\
\hline 17 & 0.077 & 0.088 & 0.107 & 0.124 \\
\hline Mean \pm SD & $0.0952 \pm 0.0141$ & $0.0969 \pm 0.0117$ & $0.1013 \pm 0.0127$ & $0.1104 \pm 0.0376$ \\
\hline
\end{tabular}

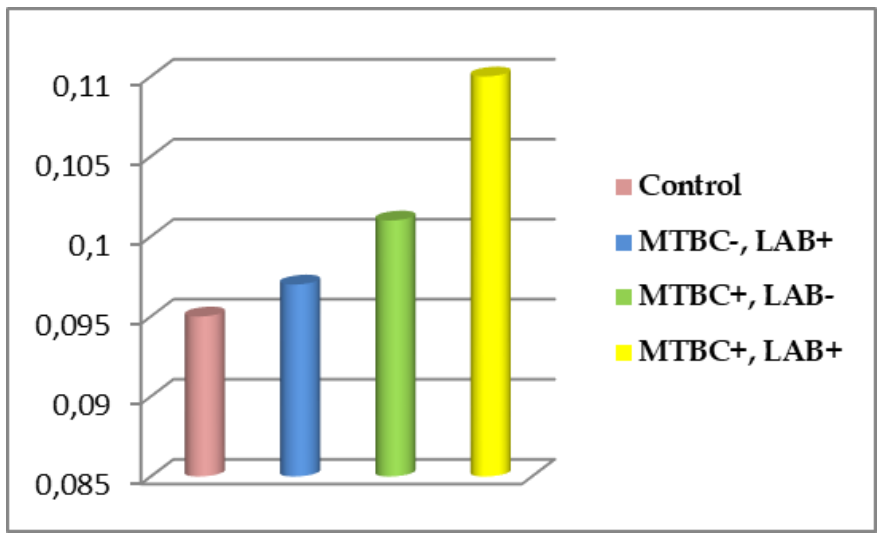

Figure 1. Average of IFN- $\gamma$ level in PBMC supernatant of control and treatment groups.

\subsection{Statistical analysis}

Anova test proved a significant difference in IFN- $\gamma$ levels $(p=0.04)$ only between the control supernatant IFN group $(-M t b C$, $-\mathrm{LAB})$ compared to the IFN- $\gamma$ treatment supernatant group $(+M t b C$, $+\mathrm{LAB})$. The analysis continued with Least Significant Different (LSD) to ascertain which groups were significantly different $(\mathrm{CI}-95 \%, \mathrm{p}<0.05)$. The LSD of serum, supernatant control, and supernatant treatment were denoted in Table 4. 
Table 4. Result of least significant different test.

\begin{tabular}{|c|c|c|c|}
\hline Sample group (SG) & Kind of Sample (SK) & Mean Difference (SG-SK) & Sig. \\
\hline \multirow[t]{4}{*}{ Serum } & Control supernatant & $-0.011647^{*}$ & 0.021 \\
\hline & Supernatant $(+M t b \mathrm{C},-\mathrm{LAB})$ & $-0.013412^{*}$ & 0.008 \\
\hline & Supernatant $(-M t b \mathrm{C},+\mathrm{LAB})$ & $-0.017765^{*}$ & 0.001 \\
\hline & Supernatant $(+M t b C,+\mathrm{LAB})$ & $-0.026471^{*}$ & 0.000 \\
\hline \multirow[t]{4}{*}{ Control supernatant } & Serum & $-0.011647^{*}$ & 0.021 \\
\hline & Supernatant $(+M t b C,-L A B)$ & -0.001765 & 0.723 \\
\hline & Supernatant $(-M t b C,+L A B)$ & -0.06118 & 0.220 \\
\hline & Supernatant $(+M t b \mathrm{C},+\mathrm{LAB})$ & $-0.14824^{*}$ & 0.004 \\
\hline \multirow[t]{4}{*}{ Supernatant $(+M t b \mathrm{C},-\mathrm{LAB})$} & Serum & $-0.13412^{*}$ & 0.008 \\
\hline & Control supernatant & -0.001765 & 0.723 \\
\hline & Supernatant $(-M t b \mathrm{C},+\mathrm{LAB})$ & -0.004353 & 0.382 \\
\hline & Supernatant $(+M t b \mathrm{C},+\mathrm{LAB})$ & $-0.013059^{*}$ & 0.010 \\
\hline \multirow[t]{4}{*}{ Supernatant $(-M t b \mathrm{C},+\mathrm{LAB})$} & Serum & -0.017765 & 0.001 \\
\hline & Control supernatant & $-0.006118^{*}$ & 0.220 \\
\hline & Supernatant $(+M t b C,-L A B)$ & $-0.004353^{*}$ & 0.382 \\
\hline & Supernatant $(+M t b C,+\mathrm{LAB})$ & -0.008706 & 0.083 \\
\hline \multirow{4}{*}{$\begin{array}{l}\text { Supernatant }(+M t b C, \\
+\mathrm{LAB})\end{array}$} & Serum & $-0.026471^{*}$ & 0.000 \\
\hline & Control supernatant & $-0.014824^{*}$ & 0.004 \\
\hline & Supernatant $(+M t b \mathrm{C},-\mathrm{LAB})$ & $-0.013050^{*}$ & 0.010 \\
\hline & Supernatant $(-M t b \mathrm{C},+\mathrm{LAB})$ & -0.008706 & 0.083 \\
\hline
\end{tabular}

The paired t-test results for samples with IFN- $\gamma$ level of untreated (as a 'pre' condition) and treated supernatant (as a 'post' condition) showed significantly different results only between IFN- $\gamma$ control group and IFN-y supernatant $(+M t b \mathrm{C},+\mathrm{LAB})$, with $\mathrm{p}=0.006$.

The $M t b$ in macrophage culture which is then followed by phagocytosis $M t b$ by macrophages is a potent signal for the production of IL-12 by activated macrophages, where the components in lipoarabinomannan (LAM) that compose the cell wall of $M t b$ is an external factor that can stimulate activated macrophages to produce IL-12 as the initial regulation of the immune response. The $M t b$ and Mycobacterial product are strong inducers for IL-12. Secretion of IL-12 will collaborate indirectly with IL-1 and TNF to stimulate T cells and NK to produce IFN- $\gamma[5,15]$.

The LAB with its activity as an immune modulator is known to have the ability to produce and maintain at least three mucosal immune system activities, namely: a) anti-microbial and pro-inflammatory abilities mediated by Th- 1 cytokines such as IL-12, TNFa and IFN- $\gamma ; b$ ) anti-inflammatory activity and oral tolerance, which are induced and maintained by Th-2 cytokines, the main ones being IL-10 and TGF- $\beta$; c) stimulation of the adaptive immune response, including local and systemic IgG and IgA synthesis mainly due to IL-4 and IL-5 [16].

The presence of two inducers (Mtb and LAB) for IFN- $\gamma$ production increased PBMC activity. This result was in line with Ghadimi's research which proved that the presence of $M t b$ antigens has been shown to increase IFN- $\gamma$ and nitric oxide (NO) secretion in PBMC culture supernatant. Addition of the LAB also caused a significant increase in the IFN- $\gamma$ secretion when compared with controls. The combination of antigen $M t b$ and LAB led to the occurrence of synergistic increase in IFN-NO and the addition of NO amount, where the increase in the occurring levels was proven to be statistically greater than the amount of IFN- $\gamma$ produced from each treatment/incubation with $M t b$ and LAB in PBMC culture [7].

It was found that the IFN- $\gamma$ levels increasedafter treatment through incubation together with LAB without $M t b(-M t b \mathrm{C},+\mathrm{LAB})$, incubation with $M t b$ and administration of $\mathrm{LAB}(+M t b \mathrm{C},+\mathrm{LAB})$ in PBMC culturesof childhood TB during treatment. This phenomenon showed that even though the $M t b$ and $\mathrm{LAB}$ were potential inducers for PBMCs toproduce IFN- $\gamma$, the increase in IFN- $\gamma$ levels induced by LAB was greater than that induced by $M t b C$.

This result was in accordance with the study of Ghadimi et al. who proved that the administration of $M t b o r$ LAB antigen caused a significant increase in IFN- $\gamma$ secretion when compared with controls. The combination of antigen Mtb with LAB Lactobacillus rhamnosus GG (LGG) and Bifidobacterium bifidum MF 20/5 $(\mathrm{Bw})$ led to the occurrence of synergistic increase in IFN- $\gamma$, where the increase in levels was proven to be 
statistically greater than the amount of IFN- $\gamma$ produced from each treatment (incubation with $M t b$ or LAB only) [7].

The results of this study need to be followed up with in vivo research to investigate ability of the LAB as an immune modulator in preventing infection in healthy animals infected with $M t b$, in order to find out how they affect the recovery process of these animals. The next studying the future will expected to be carried out clinical trials to assay the ability of LAB as an immune modulator in samples of healthy childhood with positive TB contacts and in active latent TB childhood.

\section{CONCLUSION}

The administration of multiculture of Lactic Acid Bacteria (Lactobacillus acidophilus, Lactobacillus bulgaricus, Lactobacillus casei, Bifidobacterium bifidum, Bifidobacterium animalis, Lactobacillus plantarum, Streptococcus thermophilus) liquid caused increased of IFN- $\gamma$ secretion in peripheral blood mononuclear cell culture supernatant of childhood TB treatment. The LAB increased $6.31 \%$ IFN- $\gamma$ level, while treatment with LAB and Mycobacterium tuberculosis increased IFN- $\gamma$ level up to $15.79 \%$ compared to IFN- $\gamma$ level in the PBMC without treatment.

\section{MATERIALS AND METHODS}

\subsection{Materials}

Human IFN gamma (R\&D system) Cat.No. DIF50, FBS (sigma) 100 mL Cat.No. F6178, Histo-paque (sigma) 100 mL Cat.No. 1077, Rowell Park Memorial Institute (RPMI)-1640 culture medium (Sigma, Munich, Germany), TC plate 24 well (SPL) Cat.No. 300024, ELISA Reader.

\subsection{Samples collection}

The study population was TB patients aged 2 to 14 years who were treated/underwent outpatient care at the pediatric Respirology Poly Dr. Soetomo Hospital Surabaya and Hajj Hospital Surabaya during two weeks. Samples were taken from population that met the inclusion criteria. The unit of analysis of the sample was PBMC, all blood cells that have one nucleus, namely lymphocytes, monocytes and macrophages, which were separated from peripheral blood cells using the density gradient centrifugation method using a Ficoll-Paque solution/reagent [17]. The sampling method used non probability sampling with sampling techniques consecutive sampling, where all subjects present and meeting the selection criteria were included in the study until the number of samples needed was met.

\subsubsection{Inclusion criteria}

The PBMCs of childhood TB who were diagnosed by a pediatrician and were undergoing anti-TB drug therapy at a dose adjusted to the patient's condition. Parents agreed that their children were involved in the study and were willing to sign an informed consent sheet.

\subsubsection{Exclusion criteria}

Blood samples occur hemolysis/damage, there was a drop out, there was a significant cell death in culture and cell, cannot be assessed.

\subsection{Number of samples}

The estimated sample size needed in this study was calculated based on the sample formula for in vitro design according to Federer's formula, namely: $(\mathrm{n}-1)(\mathrm{t}-1)>15$, where $(\mathrm{t})$ is the amount of treatment, and $(n)$ is the number of samples in the treatment group. The amount of treatment $(t)$ was $4: I F N-\gamma$ supernatant without any treatment, IFN- $\gamma$ supernatant incubated with $M t b$ without LAB, IFN- $\gamma$ supernatant with LAB without $M t b$, IFN- $\gamma$ supernatant with $M t b$ and LAB, then the minimum number of samples obtained for each group was 6 people. To anticipate the possibility of drop out by $10 \%$, so that the sample size used in the study is at least 7 samples per treatment group.

\subsection{Bacterial strains}

The bacterial strain of LAB used in this study was a multi culture consisted of Lactobacillus acidophilus, Lactobacillus bulgaricus, Lactobacillus casei, Bifidobacterium bifidum, Bifidobacterium animalis, Lactobacillus plantarum, and Streptococcus thermophilus obtained from the Microbiology Laboratory of the Faculty of 
Pharmacy, Univesitas Airlangga [13]. The isolates of Lactobacillus acidophilus FNCC-0051, Lactobacillus plantarum FNCC-0027, and Lactobacillus casei were obtained from the Universitas Gadjah Mada Center for Food and Nutrition Studies. Lactobacillus bulgaricus, Bifidobacterium bifidum and Bifidobacterium animalis strains were obtained from the Biology Service Unit at the Universitas Airlangga Faculty of Science and Technology. Streptococcus thermophilus strains were obtained from the Laboratory of Nutrition Biochemistry, Faculty of Animal Husbandry, Unversitas Gadjah Mada. The Mtb bacterial strain was virulent H37Rv Mtb obtained from the Tuberculosis Laboratory Institute of Tropical Disease, Universitas Airlangga.

\subsection{Data collection}

The diagnosis was made by a pediatrician based on microbiological examination (direct microscopic examination of smear/tissue biopsy to find smear/TB culture examination) and or use a scoring system with a score of $>6[18]$.

Parents of patients were given an explanation of the description of the research that will be conducted, including the purpose, benefits and procedures for examination and treatment that will be experienced by the research subject as contained in the informed consent sheet to the parents/guardians of the research subject. Parents who were willing to include their children in the study signed the informed consent sheet as the research subject. Venous blood $(5 \mathrm{~mL})$ was taken from pediatric TB patients who took place in the study.

Parents/guardians of previous research subjects were asked for their approval to do the blood collection process by signing the medical action approval sheet. The $5 \mathrm{~mL}$ venous whole blood was then put into vacutainer with EDTA and together with the ice pack sent to the ITD Laboratory, Universitas Airlangga. The IFN- $\gamma$ examination by ELISA was done using the Quantikine Human IFN- $\gamma$ immune assay Cat. kit. No. DIF5096 tests. The ELISA examination wasconformed to the standard procedures.

\subsection{Preparation of Lactic Acid Bacteria multi cultures}

Preparation of multi culture LAB was carried out in the Microbiology Laboratory of the Faculty of Pharmacy, Universitas Airlangga. Each bacteria from the stock culture was sub-culteredby taking one Öse, inoculated in the fresh of De Man Rogosa and Shaerpe (MRS, Oxoid) slant agar medium, incubated at 37०C for 24 hours [19]. The turbidity of the microorganism was adjusted to McFarland's $0.5 \mathrm{M}$ and the necessary dilution was done in order to get the final concentration as $2 \times 10^{8} \mathrm{CFU} / \mathrm{mL}$. One $\mathrm{mL}$ of the inoculum put in $10 \mathrm{~mL}$ of sterile MRS Broth and then incubated again for 48 hours to obtain LAB starter [19]. One $\mathrm{mL}$ of each starter was put into the test tube, mixed and then made serial dilution for calculating the total plate count (TPC) of the multi culture. One $\mathrm{mL}$ of the LAB multi culture input into a test tube containing $9 \mathrm{~mL}$ of saline $(\mathrm{NaCl} 0.9 \%)$ solution, homogenized with vortex, in order tomake a dilution to $10^{10}[13]$. The suspension from $10^{-4}$ to $10^{-8}$ dilutions was taken $1 \mathrm{~mL}$ and put aseptically into a sterile petri dish and added $12 \mathrm{~mL}$ of MRS agar media. The Petri dishes were shaken to homogenize, so that the bacteria spread evenly and left to solidify. The number of bacterial growth was calculated by TPC method [19]. The suspension used in this study was containing colonies of $2 \times 10^{8} \mathrm{CFU} / \mathrm{mL}$ or $2 \times 10^{7} \mathrm{CFU} / 100 \mu \mathrm{L}$.

\subsection{Preparation of Mycobacterium tuberculosis suspension cell}

The preparation of the suspension of $M t b$ was carried out in the tuberculosis laboratory of ITD, Universitas Airlangga, Surabaya. The Mtb H37Rv ATCC-27294 colonies aged 3-4 weeks in LowensteinJensen (LJ) media were taken with a loop (2 mm diameter) suspended into $5 \mathrm{~mL}$ RPMI medium (+ $3 \%$ glycerin $+10 \%$ serum 209 HIPHS) in tube + glass beads (diameter $2 \mathrm{~mm}$; 6-8 beads), vortexed until homogeneous suspention was obtained, then left 30 minutes. The upper portion of $M t b$ equivalent to $7.5 \times$ $10^{5}$ per mL (S) was taken $0.2 \mathrm{~mL}$ suspended in $3.8 \mathrm{~mL}$ RPMI (S1) until the content of $M t b$ was equivalent to $1.5 \times 10^{5} \mathrm{CFU} / \mathrm{mL}[20]$.

\subsection{Separation of PBMC}

The PBMCs preparation was carried out in the Leprosy ITD laboratory, Universitas Airlangga, Surabaya. $5 \mathrm{~mL}$ of venous whole blood patients were put into container with EDTA and together with ice packs were sent to the ITD Laboratory. Centrifugation was carried out for 10 minutes at 3,000 rpm to separatethe serum, and then taken $1 \mathrm{~mL}$, stored in deep freeze $\left(-20^{\circ} \mathrm{C}\right)$ until used for serum IFN- $\gamma$ examination [21].

The subject's vein blood was $5 \mathrm{~mL}$ in EDTA tubes, after taking a small amount of the serum, PBS $5 \mathrm{~mL}$ was added (1:1). The blood and PBS were then inserted into the falcon which contains the ficoll slowly. Centrifugation was done at $2400 \mathrm{rpm}, 400 \mathrm{~g}$ was performed for 30-40 minutes at room temperature. The 
centrifuged blood separated into 4 layers from bottom to the top, namely the sediment was erythrocytes, the ficoll, a gray white buffy coat layer like a ring; which was a mononuclear cell population and the blood plasma layer.

Buffy coat was transferred as much as possible without contamination of erythrocytes into sterile tubes, then diluted 1:3 in PBS solution, then centrifuged in histopaque (3:1, vol/vol) (Sigma chemical co, St. Louis, Mo). The fraction containing monocyte cells was transferred into a sterile centrifuge tube and rinsed with $2 x$ PBS solution. The viability of monocyte cells was determined using tryphan blue exclusion (> 95\%). The number of mononuclear cell populations obtained was calculated using the blood meter count chamber. PBMC patients was obtained with a concentration of $2 \times 10^{6}$ was then stored in deep freeze until culture was used [17].

\subsection{Preparation and treatment of PBMC}

Implementation of mononuclear cell culture and administration of the treatment was carried out in the ITD Tuberculosis Laboratory at Universitas Airlangga, Surabaya. $\pm>2 \times 10^{6} / \mathrm{mL}$ of PBMC incubated with $0.5 \times 10^{5} \mathrm{CFU} / \mathrm{mL} \mathrm{M} t b$ for 48 hours, and then treated by $\geq 2 \times 10^{8} \mathrm{CFU} / \mathrm{mL}$ multicultures and then incubated for 48 hours [7].

The isolated mononuclear cells taken $200 \mu \mathrm{L}$ were put into wells 1, 2, 3 and 4 using 24-well culture plates (Nunc, Roskilde, Denmark), then added $500 \mu \mathrm{L}$ of RPMI-1640 culture medium, 10\% FBS (called complete medium) had been added before. Incubation was carried out for 1 hour at $37^{\circ} \mathrm{C}$ and $5 \% \mathrm{CO}_{2}$. Replace RPMI $500 \mu \mathrm{L}$ by removing the previous medium and reinserting the new medium. $100 \mu \mathrm{L}$ of LAB multi cultures bacteria was added to well 2, $100 \mu \mathrm{L}$ of $M t b$ in well 3 and well 4, then incubated for $2 \times 24$ hours at $37^{\circ} \mathrm{C}$ and $5 \% \mathrm{CO}_{2}$. Ghadimiet al. treated $\pm>2 \times 10^{6} / \mathrm{mL}$ PBMC incubated with $0.5 \times 10^{5} \mathrm{CFU} / \mathrm{mL} \mathrm{M} t b$ for 48 hours [7].

The RPMI replacement was done again, and then LAB multi culture were added to the well 4 . The incubation was done again for $2 \times 24$ hours at $37^{\circ} \mathrm{C}$ and $5 \% \mathrm{CO}_{2}$.

The next process was harvest and centrifuge $1600 \mathrm{rpm}$ for 5 minutes to remove mononuclear cells. The cell-free supernatantwere then sterilized by filtering with a $0.2 \mu \mathrm{m}$ pore size (Millipore, Germany) or whited filter paper, then stored at $-80^{\circ} \mathrm{C}$ until used for IFN analysis [7].

\subsubsection{Analysis of IFN- $\gamma$ by ELISA kit}

The kit used was Quantikine Human IFN-ץ Immunoassay Cat. No. DIF50 96 tests. Assay was done by preparing the subject at room temperature, preparing all reagents and standards as specified then adding $100 \mu \mathrm{L}$ of the RD1-51 diluent assay to each well. After 100 minutes the standard subject or control was added to each well for 15 minutes, incubated for 2 hours, aspirated, and washed 4 times, then added $200 \mu \mathrm{L}$ conjugate to each well, incubated for 2 hours, aspirated, and washed 4 times. $200 \mu \mathrm{L}$ substrate solutions then added to each well. Incubation was carried out for 30 minutes by avoiding light, then ad $50 \mu \mathrm{L}$ stop solution was added each well and read at $450 \mathrm{~nm}$ for 30 minutes correction $540 \mathrm{~nm}$ or $570 \mathrm{~nm}$ [21].

\subsubsection{Data analysis}

Data from medical records, interviews, observations and examination results were then carried out by editing, coding and data entry. The data obtained were analyzed using a pair $t$ test statistical test (test for 2 paired samples) to determine the significance of IFN- $\gamma$ leveldifferences in the culture before and after treatment by incubation with $M t b$ without administration of $\mathrm{LAB}(+M t b \mathrm{C},-\mathrm{LAB}), \mathrm{LAB}$ administration without incubation with $M t b(-\mathrm{MTBC},+\mathrm{LAB})$, incubation with $M t b$ and administration of $\mathrm{LAB}(+M t b \mathrm{C}$, $+\mathrm{LAB})$. The $\mathrm{p}$ values less than 0.05 were considered significant.

Acknowledgements: This research was supported by research grant from Faculty of Medicine, Universitas Airlangga.

Author contributions: Concept - F.R., N.M.M, I.; Design - F.R., N.M.M, I.; Supervision - N.M.M, I.; Resources - F.R., N.M.M, I.; Materials - F.R., N.M.M, I.; Data Collection and/or Processing - F.R., N.M.M, I.; Analysis and/or Interpretation F.R., N.M.M, I.; Literature Search - F.R., N.M.M, I.; Writing - F.R., N.M.M, I.; Critical Reviews - F.R., N.M.M, I.

Conflict of interest statement: The authors declared no conflict of interest in the manuscript.

Ethics committee approval: This study was approved by the Universitas Airlangga Research Ethics Board (150/Panke.KKE/II/2015) and all design of research was performed in accordance with institutional guidelines and regulations. Informed written consents were obtained from all study participants. 


\section{REFERENCES}

[1] WHO Tuberculosis. http://www.who.int/mediacentre/factsheets/fs104/en/, (accessed on 6 June 2019).

[2] WHO Global tuberculosis report 2012. https://www.who.int/tb/publications/global_report/gtbr12_main.pdf, (accessed on 06 June 2019)

[3] WHO No more crying, no more dying towards zero TB deaths in children. http://www.stoptb.org/assets/documents/news/ChildhoodTB_report_singles.pdf, (accessed on 17 June 2019).

[4] Kumar V, Abbas KA, Fausto N, Robbins and Cotran Pathologic Basis of Disease, Eighth ed., Elsevier Saunders, Philadelphia, PA, US, 2010.

[5] Bhavanam S, Gina RR, Monika K, Dennis K, Steven JD. Characterization of immune responses of human PBMCs infected with Mycobacterium tuberculosis H37Ra: Impact of donor declared BCG vaccination history on immune responses and M. tuberculosis growth. Plos One. 2018; 13(9): e0203822. [CrossRef]

[6] Joost JO. Cytokines. In: Tristram GP, Daniel PS, Abba IT. (Eds). Medical Immunology, tenth ed., McGraw-Hill Medical Publishing Division, New York, 2001, pp. 95-112.

[7] Ghadimi D, de Vrese M, Heller KJ, Schrezenmeir J. Lactic acid bacteria enhance autophagic ability of mononuclear phagocytes by increasing Th1 autophagy-promoting cytokine (IFN-gamma) and nitric oxide (NO) levels and reducing Th2 autophagy-restraining cytokines (IL-4 and IL-13) in response to Mycobacterium tuberculosis antigen. Int Immunopharmacol. 2010; 10(6): 694-706. [CrossRef]

[8] Crevel V, Tom HM, Ottenhoff, Jos WM. Innate immunity to Mycobacterium tuberculosa. Clin Microbiol Rev. 2002; 15(2): 294-309. [CrossRef]

[9] Terapi imuno potensiasi atau terapi imunomodulator. https://childrenallergyclinic.wordpress.com/2010/10/23/terapi-imunopotensiasi-atau-imunomoduLasi/, (accessed on 9 June 2019).

[10] Isolauri E, Salminen S. Probiotics: use in allergic disorders: a nutrition, allergy, mucosal immunology, and intestinal microbiota (NAMI) research group report. J Clin Gastroenterol. 2008; 42(2): 91-96. [CrossRef]

[11] Isolauri EY, Sütas P, Kankaanpää, Arvilommi H, Salminen S. Probiotics: effects on immunity. Am J ClinNutr.2001; 73(2): $444-450$. [CrossRef]

[12] Isnaeni I, Idha K, Sugiyartono, Agus SR. Efek imunomodulator kombinasi susu probiotik (Lactobacillus acidophillus) dan ekstrak daun jambu biji. Jurnal Farmasi Indonesia. 2016; 8(1): 277-282. [CrossRef]

[13] Isnaeni, S. Antibacterial activities of probiotics mixed culture against methicillin resistant Staphylococcus aureus (MRSA) and extended spectrum beta lactamase (ESBL) bacteria. J Chem Pharm. 2015; 7(4): 1005-1010.

[14] Isnaeni, Maulidina A, Kusumawati I, Setyawatie EM. Inhibitory activity of Lactobacillus plantarum ATCC8014 fermented milk with aqueous combined extract of Moringaoleifera leaves against Streptococcus mutans. J Res Pharm. 2019; 23(4): 701-710. [CrossRef]

[15] Dao DN. Mycobacterium tuberculosis lipomannan inducer apoptosis and interleukin-12 production in macrophages. Infect Immun. 2004; 72(4): 2067-2074. [CrossRef]

[16] Gackowska 1, Michalkiewicz J, Krotkiewski, Helmin-Basa A, Kubiszewska I, Dzierzanowska D. Combined effect of different lab strains on the mode of cytokines pattern expression in human peripheral blood mononuclear cells. J Physiol Pharmacol. 2006; 57(9): 13-21.

[17] MACS Cell Separation Reagents data sheets, Miltenyi Biotec GmbH 2008. https://www.miltenyibiotec.com, (accessed on 14 May 2019).

[18] Departemen Kesehatan RI-IDAI, Diagnosis dan Tatalaksana Tuberkulosis anak, Departemen Kesehatan Republik Indonesia, Jakarta, JKT, ID, 2008.

[19] Dian DA. Magister Thesis. Pengaruh bakteri probiotik dari berbagai sumber terhadap aktivitas imunoglobulin $g$ (IgG) pada mencit jantan (Mus musculus). Faculty of Pharmacy, Universitas Hasanuddin, Tamalanrea, Makassar, Indonesia, 2011.

[20] Linawati M, Baginda M, Pengaruh propolis terhadap sekresi interleukin-12 pada supernatant kultur makrofag dari penderita tuberculosis paru yang diinfeksi Mycobacterium tuberculosis, RSUP Sanglah Denpasar Bali, Denpasar, DPS, ID, 2006

[21] R\&D System, Technical Datasheet. Quantikine Human IFN- $\gamma$ Immunoassay. For the quantitative determinations in cell culturesupernates, serum, and plasma. Catalog Number DIF 50, R\&D Systems Inc, Minneapolis, MN, US, 2018.

This is an open access article which is publicly available on our journal's website under Institutional Repository at http://dspace.marmara.edu.tr. 